\title{
Cost variation study of antidepressant drugs
}

\author{
Ajay Kumar Shukla ${ }^{1}$, Parag Sharma ${ }^{2}$
}

${ }^{1}$ Department of Pharmacology, Gandhi Medical College,

Bhopal (M.P.), India

${ }^{2}$ Department of Pharmacology, L.N. Medical College, Bhopal

(M.P.), India

Received: 16 July 2016

Accepted: 26 July 2016

*Correspondence to:

Dr. Ajay Kumar Shukla,

Email: drajay1024@gmail.com

Copyright: (C) the author(s), publisher and licensee Medip Academy. This is an openaccess article distributed under the terms of the Creative Commons Attribution NonCommercial License, which permits unrestricted noncommercial use, distribution, and reproduction in any medium, provided the original work is properly cited.

\begin{abstract}
Background: Depression and anxiety disorders are the most common mental illnesses, each affecting in excess of $10-15 \%$ of the population at some time in their lives. Approximately $10-15 \%$ of those with severe depression attempt suicide at some point of time. Thus, it is important that symptoms of depression be recognized and treated appropriately.

Methods: The prices of 15 antidepressant drugs, available in 43 different formulations were analyzed. Costs of different brands of a particular generic antidepressant drug being manufactured by different companies, in the same strength and dosage forms were used to calculate cost ratio and percentage cost variation.

Results: This study shows that there is a wide variation in the prices of different brands of same antidepressant drug in Indian market. The highest cost ratio and percent cost variation was found for amitriptyline $50 \mathrm{mg}$, followed by bupropion $25 \mathrm{mg}$, amitriptyline $75 \mathrm{mg}$ and dosulepin $50 \mathrm{mg}$. Highest number of brands of antidepressant drugs available in Indian market are for escitalopram $10 \mathrm{mg}$ followed by escitalopram $5 \mathrm{mg}$ and $20 \mathrm{mg}$.

Conclusions: There is wide price variation of different brands of the same generic antidepressant drug in Indian market. Cost of a drug plays an important role in treatment of depression as it follows a long course and adherence to the treatment is related with drug cost. To decrease the wide cost variation among different brands of antidepressant drugs; it is high time to generate physician awareness about impact of cost effectiveness of drug regimen and for regulation of drug prices by the concerned agencies.
\end{abstract}

Keywords: Cost analysis, Compliance, Adherence, Depression, Health Economics, Cost variation

\section{INTRODUCTION}

Depression and anxiety disorders are the most common mental illnesses, each affecting in excess of $10-15 \%$ of the population at some time in their lives. Lifetime risk of unipolar depression is $\sim 15 \% .{ }^{1}$ Depression is underdiagnosed and undertreated. ${ }^{2}$ This is of particular concern due to the inherent risk of suicide associated with depression. Approximately $10-15 \%$ of those with severe depression attempt suicide at some point of time. ${ }^{3}$ Thus, it is important that symptoms of depression be recognized and treated appropriately.

For treatment of major depression, many antidepressant drugs have established track records of efficacy. ${ }^{4}$
Selective serotonin reuptake inhibitors (SSRIs) and the serotonin-norepinephrine reuptake inhibitors (SNRIs) have greater efficacy and safety compared to most of the older antidepressant drugs. ${ }^{1}$

Response to the antidepressant drug treatment is evident following 3-4 weeks of initiation of treatment. ${ }^{1}$ About one third of the depressed patients have a complete remission with a single antidepressant drug. ${ }^{5}$ If a partial response is observed, then other drug may be added to primary SSRI or SNRI medication. This additional medication can be bupropion, thyroid hormone, or an atypical antipsychotic (aripiprazole or olanzapine). ${ }^{6}$ If a patient does not respond to 8 weeks of antidepressant treatment, then switching to another antidepressant medication with a different 
mechanism of action is done. Successful initial treatment phase is followed by maintenance phase. After 6-12 months of maintenance phase, the drug is gradually withdrawn. If the patient is chronically depressed (i.e., >2 years), or had two separate episodes of major depression, lifelong antidepressant treatment is advisable. ${ }^{1}$

Indian markets have a number of branded formulations for antidepressant medications with variable pricing difference between the different brands of the same formulation. The difference in cost between different brands of the same drug is large, leading to unfair burden on the patients. ${ }^{7}$

Cost-sensitive healthcare environment is a competitive and challenging workplace for healthcare professionals. It is challenging for healthcare professionals to provide quality patient care and assuring an efficient use of resources. ${ }^{8}$

In India, majority of the health care costs are afforded by the patients. India is one of those countries who have highest Out Of Pocket (OOP) expenses on health care. India is among the largest manufacturers of generic drugs while about $65 \%$ of Indians lacks access to essential medicines. $^{9}$

High medical care costs should be a cause of concern for policy makers and service providers. ${ }^{10}$ It has been observed that there is lack of appreciation among the physicians for the cost difference between the inexpensive and expensive drugs. ${ }^{11}$ This can be attributed to the fact that pharmacoeconomical aspect of a treatment regimen are not taught during their undergraduate and postgraduate study period. It has also been observed that physicians often underestimate the cost of expensive drugs while overestimating the inexpensive ones. This can result in increased overall medical care costs. ${ }^{12}$

Drug price control order (DPCO) is an important tool of the government to fix prices of drug. Drugs which are brought under DPCO cannot be sold at a price higher than the price fixed by the government.

Treatment of depression follows a long course of duration. For the successful treatment of depression, adherence to the treatment regimen is desirable. Decreased drug cost is associated with improved adherence to the medication regimen. ${ }^{13}$ High medical care cost is a matter of concern for patients as well as for policy makers and service providers. ${ }^{12}$ Thus, high drug cost leads to noncompliance which leads to treatment failure resulting in higher medical care costs. Creating awareness about the advantages of decreasing the drug cost can play an important role in preventing it.

This study was aimed at investigating and comparing the costs of various brands of the same generic antidepressant agent, so that we can evaluate cost variations among them. Awareness of the cost variations among antidepressant drugs can be utilized to employ more economical treatment regimen to improve the patient compliance and the rate of success of therapy.

\section{METHODS}

The prices of 15 antidepressant drugs, available in 43 different formulations were analyzed.

1. Cost of a particular drug (cost per 10 tablets), in the same strength and dosage forms being manufactured by different companies was obtained from "Current Index of Medical Specialties” (CIMS) January-April 2016.

2. The drugs being manufactured by only one company or being manufactured by different companies; however, in different strengths were excluded.

3. The cost ratio, the ratio of the highest cost brand to lowest cost brand of the same generic antidepressant drug was calculated. For each generic antidepressant drug, we calculated that how many times costliest brand costs more than the cheapest brand.

4. Percentage cost variation was calculated as follows: ${ }^{11}$

$$
\text { Cost variation }(\%)=\frac{\text { Max. cost }- \text { Min. Cost }}{\text { Min. } \text { cost }} \times 100
$$

\section{RESULTS}

This study shows that there is a wide variation in the prices of different brands of same antidepressant drug in Indian market. The highest cost ratio (1:5.68) and percent cost variation (468) was found for amitriptyline $50 \mathrm{mg}$, followed by bupropion $25 \mathrm{mg}$ ((1:5.19) and 419), amitriptyline $75 \mathrm{mg}((1: 3.33)$ and 233) and dosulepin $50 \mathrm{mg}((1: 2.81)$ and 181) (Table 1). Highest number of brands of antidepressant drugs available in Indian market are of escitalopram $10 \mathrm{mg}$ (24) followed by escitalopram $5 \mathrm{mg}$ (17) and $20 \mathrm{mg}$ (16) (Table 2).

Table 1: Variation in cost of antidepressant drugs.

\begin{tabular}{|llllll|}
\hline Antidepressant Drug & Strength & Min. Cost (INR) & Max. Cost (INR) & Cost ratio & \% Cost Variation \\
\hline \multirow{3}{*}{ Amitriptyline } & $10 \mathrm{mg}$ & 9.00 & 24.40 & 2.71 & 171.11 \\
\cline { 2 - 6 } & $25 \mathrm{mg}$ & 16.00 & 37.00 & 2.31 & 131.25 \\
\cline { 2 - 6 } & $50 \mathrm{mg}$ & 18.30 & 104.00 & 5.68 & 468 \\
\hline
\end{tabular}




\begin{tabular}{|c|c|c|c|c|c|}
\hline & $75 \mathrm{mg}$ & 20.00 & 66.60 & 3.33 & 233 \\
\hline \multirow{2}{*}{ Amoxapine } & $50 \mathrm{mg}$ & 38.82 & 53.50 & 1.38 & 37.8 \\
\hline & $100 \mathrm{mg}$ & 71.93 & 98.00 & 1.36 & 36.24 \\
\hline Bupropion & $150 \mathrm{mg}$ & 77.00 & 400.00 & 5.19 & 419 \\
\hline \multirow{3}{*}{ Citalopram } & $10 \mathrm{mg}$ & 22.00 & 38.50 & 1.75 & 75 \\
\hline & $20 \mathrm{mg}$ & 40.00 & 67.00 & 1.67 & 67.5 \\
\hline & $40 \mathrm{mg}$ & 75.00 & 118.00 & 1.57 & 57.3 \\
\hline \multirow{3}{*}{ Dosulepin } & $25 \mathrm{mg}$ & 17.00 & 42.00 & 2.47 & 147 \\
\hline & $50 \mathrm{mg}$ & 27.00 & 76.00 & 2.81 & 181.4 \\
\hline & $75 \mathrm{mg}$ & 39.50 & 95.50 & 2.41 & 141.7 \\
\hline \multirow{4}{*}{ Duloxetine } & $20 \mathrm{mg}$ & 35.00 & 62.38 & 1.78 & 78.22 \\
\hline & $30 \mathrm{mg}$ & 55.00 & 77.79 & 1.41 & 41.4 \\
\hline & $40 \mathrm{mg}$ & 79.00 & 93.60 & 1.18 & 18.4 \\
\hline & $60 \mathrm{mg}$ & 119.50 & 140.40 & 1.17 & 17.4 \\
\hline \multirow{3}{*}{ Escitalopram } & $5 \mathrm{mg}$ & 23.80 & 44.00 & 1.84 & 84.8 \\
\hline & $10 \mathrm{mg}$ & 30.00 & 73.00 & 2.43 & 143.33 \\
\hline & $20 \mathrm{mg}$ & 75.00 & 136.40 & 1.81 & 81.86 \\
\hline \multirow{2}{*}{ Fluoxetine } & $20 \mathrm{mg}$ & 26.85 & 52.80 & 1.96 & 96.6 \\
\hline & $60 \mathrm{mg}$ & 59.00 & 90.00 & 1.52 & 52.5 \\
\hline \multirow{2}{*}{ Fluvoxamine } & $50 \mathrm{mg}$ & 100.00 & 121.50 & 1.21 & 21.5 \\
\hline & $100 \mathrm{mg}$ & 160.85 & 215.00 & 1.33 & 33.66 \\
\hline \multirow{3}{*}{ Imipramine } & $25 \mathrm{mg}$ & 8.30 & 13.58 & 1.63 & 63.6 \\
\hline & $75 \mathrm{mg}$ & 21.00 & 27.48 & 1.3 & 30.85 \\
\hline & $400 \mathrm{mg}$ & 20.00 & 25.00 & 1.25 & 25 \\
\hline \multirow{3}{*}{ Mirtazapine } & $7.5 \mathrm{mg}$ & 35.00 & 38.00 & 1.08 & 8.57 \\
\hline & $15 \mathrm{mg}$ & 60.00 & 62.00 & 1.03 & 3.33 \\
\hline & $30 \mathrm{mg}$ & 110.00 & 115.00 & 1.04 & 4.5 \\
\hline \multirow{6}{*}{ Paroxetine } & $10 \mathrm{mg}$ & 70.00 & 87.50 & 1.25 & 25 \\
\hline & $12.5 \mathrm{mg}$ & 80.00 & 109.00 & 1.36 & 36.25 \\
\hline & $20 \mathrm{mg}$ & 100.00 & 110.00 & 1.1 & 10 \\
\hline & $25 \mathrm{mg}$ & 112.00 & 130.00 & 1.16 & 16.07 \\
\hline & $30 \mathrm{mg}$ & 140.00 & 155.00 & 1.1 & 10.7 \\
\hline & $37.5 \mathrm{mg}$ & 160.00 & 190.00 & 1.18 & 18.75 \\
\hline \multirow{3}{*}{ Sertraline } & $25 \mathrm{mg}$ & 20.00 & 30.00 & 1.5 & 50 \\
\hline & $50 \mathrm{mg}$ & 35.00 & 45.00 & 1.28 & 28.57 \\
\hline & $100 \mathrm{mg}$ & 50.00 & 70.00 & 1.4 & 40 \\
\hline \multirow{3}{*}{ Trazodone } & $25 \mathrm{mg}$ & 17.00 & 18.00 & 1.05 & 5.88 \\
\hline & $50 \mathrm{mg}$ & 32.00 & 34.00 & 1.06 & 6.25 \\
\hline & $100 \mathrm{mg}$ & 41.00 & 45.15 & 1.1 & 10.12 \\
\hline \multirow{2}{*}{ Venlafaxine } & $37.5 \mathrm{mg}$ & 25.00 & 52.00 & 2.08 & 108 \\
\hline & $75 \mathrm{mg}$ & 47.00 & 98.00 & 2.08 & 108.5 \\
\hline
\end{tabular}

Table 2: Brands and formulations of antidepressant drug.

\begin{tabular}{|c|c|c|c|}
\hline Antidepressant drug & Strength & Formulations & Brands \\
\hline \multirow{4}{*}{ Amitriptyline } & $10 \mathrm{mg}$ & \multirow{4}{*}{4} & 12 \\
\hline & $25 \mathrm{mg}$ & & 15 \\
\hline & $50 \mathrm{mg}$ & & 5 \\
\hline & $75 \mathrm{mg}$ & & 8 \\
\hline \multirow{2}{*}{ Amoxapine } & $50 \mathrm{mg}$ & \multirow{2}{*}{2} & 3 \\
\hline & $100 \mathrm{mg}$ & & 3 \\
\hline Bupropion & $150 \mathrm{mg}$ & 1 & 2 \\
\hline \multirow{2}{*}{ Citalopram } & $10 \mathrm{mg}$ & \multirow{2}{*}{3} & 3 \\
\hline & $20 \mathrm{mg}$ & & 3 \\
\hline
\end{tabular}




\begin{tabular}{|c|c|c|c|}
\hline & $40 \mathrm{mg}$ & & 3 \\
\hline \multirow{3}{*}{ Dosulepin } & $25 \mathrm{mg}$ & \multirow{3}{*}{3} & 4 \\
\hline & $50 \mathrm{mg}$ & & 3 \\
\hline & $75 \mathrm{mg}$ & & 4 \\
\hline \multirow{4}{*}{ Duloxetine } & $20 \mathrm{mg}$ & \multirow{4}{*}{4} & 13 \\
\hline & $30 \mathrm{mg}$ & & 9 \\
\hline & $40 \mathrm{mg}$ & & 5 \\
\hline & $60 \mathrm{mg}$ & & 4 \\
\hline \multirow{3}{*}{ Escitalopram } & $5 \mathrm{mg}$ & \multirow{3}{*}{3} & 17 \\
\hline & $10 \mathrm{mg}$ & & 24 \\
\hline & $20 \mathrm{mg}$ & & 16 \\
\hline \multirow{2}{*}{ Fluoxetine } & $20 \mathrm{mg}$ & \multirow{2}{*}{2} & 11 \\
\hline & $60 \mathrm{mg}$ & & 7 \\
\hline \multirow{2}{*}{ Fluvoxamine } & $50 \mathrm{mg}$ & \multirow{2}{*}{2} & 4 \\
\hline & $100 \mathrm{mg}$ & & 4 \\
\hline \multirow{2}{*}{ Imipramine } & $25 \mathrm{mg}$ & \multirow{2}{*}{2} & 5 \\
\hline & $75 \mathrm{mg}$ & & 4 \\
\hline \multirow{3}{*}{ Mirtazapine } & $7.5 \mathrm{mg}$ & \multirow{3}{*}{3} & 3 \\
\hline & $15 \mathrm{mg}$ & & 4 \\
\hline & $30 \mathrm{mg}$ & & 2 \\
\hline \multirow{6}{*}{ Paroxetine } & $10 \mathrm{mg}$ & \multirow{6}{*}{6} & 3 \\
\hline & $12.5 \mathrm{mg}$ & & 8 \\
\hline & $20 \mathrm{mg}$ & & 3 \\
\hline & $25 \mathrm{mg}$ & & 7 \\
\hline & $30 \mathrm{mg}$ & & 3 \\
\hline & $37.5 \mathrm{mg}$ & & 3 \\
\hline \multirow{3}{*}{ Sertraline } & $25 \mathrm{mg}$ & \multirow{3}{*}{3} & 4 \\
\hline & $50 \mathrm{mg}$ & & 8 \\
\hline & $100 \mathrm{mg}$ & & 4 \\
\hline \multirow{3}{*}{ Trazodone } & $25 \mathrm{mg}$ & \multirow{3}{*}{3} & 2 \\
\hline & $50 \mathrm{mg}$ & & 2 \\
\hline & $100 \mathrm{mg}$ & & 2 \\
\hline \multirow{2}{*}{ Venlafaxine } & $37.5 \mathrm{mg}$ & \multirow{2}{*}{2} & 7 \\
\hline & $75 \mathrm{mg}$ & & 7 \\
\hline
\end{tabular}

\section{DISCUSSION}

In this study, it was found that there exists a wide cost variation among the different brands of same antidepressant drugs in Indian market. The highest cost ratio and percent cost variation was found for amitriptyline $50 \mathrm{mg}$, followed by bupropion $25 \mathrm{mg}$, amitriptyline $75 \mathrm{mg}$ and dosulepin $50 \mathrm{mg}$. Antidepressant drug with maximum number of brands are escitalopram $10 \mathrm{mg}$ (24) followed by escitalopram $5 \mathrm{mg}$ (17) and 20 $\mathrm{mg}$ (16). Amitriptyline $50 \mathrm{mg}$ and $75 \mathrm{mg}$ have been added in National list of essential medicines (NLEM) 2015. This will decrease the existing wide cost variation as their price will now be regulated under DPCO 2013.

In National list of essential medicines (NLEM) 2011, tablet amitriptyline $25 \mathrm{mg}$ was included while in NLEM 2015, amitriptyline $10 \mathrm{mg}, 25 \mathrm{mg}, 50 \mathrm{mg}$, and $75 \mathrm{mg}$ have been included. Among antidepressants drugs, amitriptyline $(25 \mathrm{mg})$, fluoxetine $(20 \mathrm{mg})$ and imipramine
(25 mg \& $75 \mathrm{mg}$ ) were the part of NLEM 2011 while amitriptyline $(10 \mathrm{mg}, 25 \mathrm{mg}, 50 \mathrm{mg}, \& 75 \mathrm{mg})$, fluoxetine (10 mg, $20 \mathrm{mg}, 40 \mathrm{mg}, \& 60 \mathrm{mg})$, escitalopram $(5 \mathrm{mg}, 10$ $\mathrm{mg}, \& 20 \mathrm{mg})$ and clomipramine $(10 \mathrm{mg}, 25 \mathrm{mg} \& 75$ $\mathrm{mg}$ ) have been included in NLEM 2015. Thus, it can be deduced that in NLEM 2015, more strengths of antidepressants drugs have been included as compared to NLEM 2011.

NLEM 2011 had 348 medicines which were increased to 376 medicines in 2015. Thus, number of drugs covered under the price regulation by DPCO 2013 have increased. ${ }^{14}$

In Indian scenario, a majority of health expenditure is out of pocket. Significant portion of this health expenditure is on medicines. In India, the health insurance schemes are underutilized. The most vulnerable groups are fully dependent on the out of the pocket spending for purchase of medicines. Many states are providing free medicine. 
The NLEM may act as a guidance document for governments to frame strategy in this regard. ${ }^{14}$

Higher medication costs can play an important role for medication nonadherence. ${ }^{15}$ Increasing cost sharing among patients is related with decreased medication adherence which ultimately results in poorer health outcomes. $^{16}$

In India, more than $80 \%$ of health financing is borne by patients. ${ }^{17}$ Majority of patients in India are paying out of their pockets for their medical bills. ${ }^{18}$

There is no correlation between the quality of medicines and their corresponding prices. Their prices have been found to be correlated with their marketing strategies. ${ }^{19}$

It has been found that there is lack of concern among the doctors about the magnitude of cost variation of drugs. Doctors usually overestimate the price of inexpensive drugs and underestimate the price of expensive ones. This tendency among doctors ultimately leads to increased overall drug expenditures. $^{12}$

Provision of readily available drug manual with comparative drug prices can ensure the doctor's awareness about the cost variations among same generic medications. This can play an important role in decreasing patient's drug expense. ${ }^{20}$ Decreased drug cost is an important factor for improved adherence to the medication regimen. ${ }^{13}$ It has been found that there is wide cost variation among different brands of the same generic antiepileptic drugs in Indian market. ${ }^{21}$

Undergraduate and postgraduate medical education curriculum must include pharmacoeconomics to ensure provision of better and economical health related services.

Fewer adverse seizure-related clinical outcomes and better treatment adherence was associated with generic antiepileptic drugs as compared to brand-name versions. ${ }^{22}$

Currently, very few antidepressant medications are covered under drug prices control order (DPCO). Hence, it is high time that the government should bring more antidepressant drugs under price control.

To improve affordability of antidepressant drugs in Indian population, due consideration must be given to their pricing. Improving physician awareness about pharmacoeconomics, increasing the number of antidepressant drugs covered under DPCO and sensitization about impact of cost of drugs as a part of medical education and provision of drug manual of comparative prices can play an important role in reinforcing cost effective drug therapy of depression.

\section{CONCLUSION}

There is wide price variation of different brands of the same generic antidepressant drug in Indian market. Cost of a drug plays an important role in treatment of depression as it follows a long course and adherence to the treatment is related with drug cost. To decrease the wide cost variation among different brands of antidepressant drugs; it is high time to generate physician awareness about impact of cost effectiveness of drug regimen and for regulation of drug prices by the concerned agencies.

\section{Funding: No funding sources \\ Conflict of interest: None declared \\ Ethical approval: Not required}

\section{REFERENCES}

1. O' Donnell JM, Shelton RC. Drug therapy of depression and anxiety disorders. In: Brunton LB,Chabner BA, Knollman BC, editors. Goodman and Gilman's The Pharmacological Basis of Therapeutics. $12^{\text {th }}$ ed. New York, NY: McGraw-Hill; 2011:397-414.

2. Suominen KH, Isometsa ET, Henriksson MM, Ostamo AI, Lönnqvist JK. Inadequate treatment for major depression both before and after attempted suicide. Am J Psychiatry. 1998;155:1778-80.

3. Chen YW, Dilsaver SC. Lifetime rates of suicide attempts among subjects with bipolar and unipolar disorders relative to subjects with other Axis I disorders. Biol Psychiatry. 1996;39:896-9.

4. Millan MJ. Multi-target strategies for the improved treatment of depressive states: Conceptual foundations and neuronal substrates, drug discovery and therapeutic application. Pharmacol Ther. 2006;110:135-70

5. Rush AJ, Trivedi MH, Wisniewski SR, Nierenberg AA, Stewart JW, Warden D, et al. Acute and longerterm outcomes in depressed outpatients requiring one or several treatment steps: A STAR*D report. Am J Psych. 2006;163:1905-17.

6. Shelton RC. Augmentation strategies to increase antidepressant efficacy. J Clin Psych. 2007;68(Suppl 10):18-22.

7. Das SC, Mandal M, Mandal SC. A critical study on availability and price variation between different brands: Impact on access to medicines. Indian $\mathbf{J}$ Pharm Sci. 2007;69(1):160-3.

8. DiPiro JT, Lamber RL, Yee GC, Matzke GR, Wells BG, Posey LM. Pharmacoeconomics: Principles, Methods, and Applications. Pharmacotherapy: a Pathophysiologic Approach. 19e. New York, NY: McGraw-Hill; 2011:01.

9. Operational Guidelines on Free drug service Initiative. National Health Mission. Available at https://mpphscl.in/Files/PDF/b731acad-eded-43b6b286- 
99aea308b1fb_0_Free_Drugs_Service_Intitiative.pd f. last accessed on 2016 July 22.

10. Gupta SK. Proposed Pharmacoeconomics Guidelines for India (PEG-I).IPSOR India Chapter;2013:79-100.

11. Akila L, Rani RJ. Cost analysis of different brands of antianginal drugs available in India. Int $\mathrm{J}$ Basic Clin Pharmacol. 2015;4:860-3.

12. Allan GM, Lexchin J, Wiebe N. Physician awareness of drug cost: A systematic review. PLoS Med. 2007;4(9):e283.

13. Shrank WH, Hoang T, Ettner SL, Glassman PA, Nair K, DeLapp D, et al. The implications of choice: prescribing generic or preferred pharmaceuticals improves medication adherence for chronic conditions. Arch Intern Med. 2006;166(3):332-7.

14. National list of essential medicines 2015. Available at http://www.drugscontrol.org/pdf/NLEM2015.pdf. Last accessed on 2016 July 22.

15. Ho PM, Bryson CL, Rumsfeld JS. Medication Adherence: Its Importance in Cardiovascular Outcomes. Circulation. 2009;119:3028-35.

16. Eaddy MT, Cook CL, O’Day K, Burch SP, Cantrell CR. How Patient cost-sharing trends affect adherence and outcomes: a literature review. Pharm Therapeut. 2012;37(1):45-55.

17. Creese A, Kotwani A, Kutzin J, Pillay A. Evaluating pharmaceuticals for health policy in low and middle income country settings. In: Freemantle N, Hill S, editors. Evaluating pharmaceuticals for health policy and reimbursement. Massachusetts, USA: Blackwell Publication; (in collaboration with WHO Geneva); 2004:227-43.

18. World Health Organisation. Essential drugs and medicines: Drug finance. Available at http://www.whoindia.org/EN/Section2/Section/Secti on160_959.html. Accessed 12 September 2014.

19. Singal GL, Nanda A, Kotwani A. A comparative evaluation of price and quality of some branded versus branded-generic medicines of the same manufacturer in India. Indian $\mathrm{J}$ Pharmacol 2011;43:131-6.

20. Frazier LM, Brown JT, Divine GW, Fleming GR, Philips NM, Siegal WC, et al. Can physician education lower the cost of prescription drugs? A prospective, controlled trial. Ann Intern Med. 1991;115(2):116-21.

21. Shukla AK, Mehani R. Cost analysis of antiepileptic drugs available in India. Int $\mathbf{J}$ Basic Clin Pharmacol 2016;5(4):1636-40.

22. Gagne JJ, Kesselheim AS, Choudhry NK, Polinski JM, Hutchins D, Matlin OS et al. Comparative effectiveness of generic versus brand-name antiepileptic medications. Epilepsy Behav. 2015;52(Pt A):14-8.

Cite this article as: Shukla AK, Sharma P. Cost variation study of antidepressant drugs. Int J Basic Clin Pharmacol 2016;5:1816-21. 